\title{
BARRIERS OF THE INTERNATIONALIZATION IN SMES IN TRANSITION COUNTRIES: EVIDENCE AND METHODOLOGICAL SUGGESTION IN CASE OF MONGOLIA
}

\author{
Ulziimaa Altnaa ${ }^{1}$, Neszmélyi György Iván² \\ ${ }^{1} \mathrm{PhD}$ student, ${ }^{2}$ Professor \\ ${ }^{1}$ Budapest Business School, Doctoral School of Entrepreneurship and Management \\ ${ }^{2}$ Budapest Business School, Faculty of Commerce, Hospitality and Tourism \\ e-mail: Ulziimaa.Altnaa.28@unibge.hu', Neszmelyi.Gyorgy@uni-bge.hu²
}

\begin{abstract}
Globally, Small and Medium-Sized Enterprises (SMEs) have been recognized as pivotal contributors to the country's economy. The main goal of this paper is to investigate country specific barriers to the internationalization process in SMEs in the transition country's context. SMEs in transition countries deal with the common challenges that are usually occurred in other economies as well and they also have to overcome challenges of institutional external and internal barriers during their internationalization. We set and suggest a mixed-method research design to explore barriers to the SMEs' internationalization phenomenon in transition countries from various perspectives using diverse approaches as Mongolia as a case. By this paper, we can contribute to the narrow existing literature in the field of the internationalization of SMEs in the transition countries by investigating SMEs in Mongolia so as to provide implications to researchers, practitioners, policymakers, and SME owners or managers.
\end{abstract}

Kulcsszavak: Small to medium-sized enterprises, Internationalization, Transition countries, Mongolia

JEL besorolás: F23, L25, R12

LCC: HD2709-2930.7

\section{Introduction}

All around the world, Small and Medium-sized Enterprises (SMEs) have been recognized as pivotal contributors to the country's economy to a great extent (Toulova et al., 2015, Doojav et al., 2020). As of 2019, SMEs account for more than $90 \%$ of all businesses in the world, generate $40 \%$ to $50 \%$ of GDP and create over $70 \%$ of total jobs on average (Lkhagvasuren- Xuexi, 2014, Tuul- Bing, 2019). Considering that SMEs also have crucial roles in creating economic growth, job opportunities, technological advancements, new value-added products, and increase in tax revenues, and alleviating poverty and income inequality, especially in developing countries (Hutchinson et al., 2009, Ngoma et al., 2017). This pattern is to be seen the same in Mongolia, which around $90 \%$ of total enterprises running business in Mongolia fall in the category of SMEs in line with the National Statistical Office's 2018's census. In addition to this, SMEs in Mongolia generate $17.8-20 \%$ of GDP, create $67-70 \%$ of the total job opportunity, and make up $2.3 \%$ of total export (Lkhagvasuren- Xuexi, 2014, Ganbold.M, 2016, Zolzaya- Hong 2018). Therefore, SMEs' key features of being resilient to dynamic changes and innovative potential are of interest to many policymakers and researchers in the world who are interested in boosting and thriving their country's economic development (Toulova et al., 2015).

Internationalization is a phenomenon that composes of export, foreign trade activities, cross border clustering, cross border collaboration, establishing subsidiaries, branches, and joint ventures stages, and through which the enterprise expands their business activities and trade 
into the different geographical area (Singh et al., 2010 and Mendy-Rahman, 2019). However, as noted in the formerly conducted studies, internationalization phenomenon is considered mainly in conjunction with big companies whose financial power is believed to be sufficient embedding on global markets and competing in fierce competition (Toulova et al., 2015). Yet, in the 21 st century, the new pattern of internationalization for firms has been emerged both in the developed and developing countries, in especially, the number of SMEs in the developing countries took action to go international market intensively has increased, even though they have limited resource and capacities compared to the big multinationals. Besides, the rapid globalization and less trade barriers accelerate SMEs internationalization process more than ever before, and policymakers of countries commenced to develop brand new policy approaches supporting domestic SMEs' internationalization process as a vehicle for social and economic prosperity (Al-Hyari et al., 2012). There are many factors that are used to explain SMEs internationalization process, including the proactive and reactive reasons, motives, or drivers. Extant research studied these issues using many approaches, but attention paid to the firm- and context-specific factors is limited, especially concerning SMEs in transition contexts due to most studies conducted in a developed country context. Therefore, we hope that our study will make great contributions to the specifics related to what are the main barriers of the internationalization process in SMEs in the transition country context significantly.

\section{Literature review}

In line with the World Trade Organization (WTO) census, the rapid SME's internationalization brought an upsurge in global trade and export rate. Singh et al (2010) pointed out that export activity is concerned as crucial because it increases budget revenue, enhances trade balances, assists in alleviating issues raising from poverty and unemployment. Also, export growth generates employment opportunities in the local economy that might improve standards of living (Kahiya, E.T., 2013). Consistent with it, Organization for Economic Cooperation and Development (OECD) stated that export is the most common entry mode that is used to enter into foreign market for SMEs because exporting process does not require many prerequisites and a large amount of capital investment, yet this kind of entry comes up with less financial and commercial risk compared to other direct investment modes (Al-Hyari et al., 2012, Kahiya, E.T., 2013, Roy et al., 2016). A result of rapid globalization followed by economic, financial, credit crises, and rock-bottom of consumer confidence throughout the world has led to the domestic market saturation phenomenon. Consequently, the local SMEs and MNEs have started to look for new markets to enter and expand their business activities towards abroad as an exporter at first (Gardó et al., 2015). Exporting to different geographical locations enhances a firm's competitive advantage, which brings forward more productivity and efficiency in terms of operations compared to non-exporting firms (Kahiya, E.T., 2013).

There are many influential factors, including motives, drivers, impediment factors, and internal and external capabilities, for the internationalization phenomenon. Among them, investigating the barriers -impediments- is crucial in a regard to speed of internationalization for the reason that it might be helpful to comprehend SMEs' low-level export (Toulova et al., 2015) in Mongolia, which leads to reduce the barriers and increase overall export performance. Mongolian economy is hugely dependent on the resource sector accounting for $90 \%$ of total export and $25 \%$ of budget revenue. The experts highlighted that there is a huge need to diversify economy by supporting SMEs development (Doojav et al., 2020). Although SMEs produce relatively low level of value-added products/ services and exports in Mongolia, they are dominant in terms of magnitude and employment. As of 2019, SMEs in Mongolia provide 67\% of the total job opportunity, produce $20 \%$ of GDP, and generate $2.3 \%$ of total export (Ganbold.M, 2016, Zolzaya- Hong, 2018). Compared to neighbors' countries, Mongolian 
SMEs have contributed less amount of share in export, 2.3\%, as Taiwan 31.4\%, China $68 \%$, Japan 20.3\%, and the Republic of Korea 16\% (Yener et al., 2014).

Facing barriers to the internationalization process is different for every country in the context of arising problems, especially, depending on the level of economic development (Toulova et al., 2015). In line with Toulova et al (2015) and Booltink,-Saka-Helmhout (2018), the previous studies mostly focus on MNEs or big, well-established firms in the developed countries. In terms of geographical location, most papers exploring barriers to the export of SMEs has been conducted in the USA, Europe, and some Asian big markets, including China, Singapore, Japan, and South Korea (Hovhannisyan-Vasa, 2007, Al-Hyari et al., 2012) or even the examples of the Central Asian countries (Gyene, P. 2020). There have been only a few pieces of research studied barriers impeding the SME's foreign market entry and export related activity from the transition country context, especially choosing Mongolia as a case. Mongolia's possible role and participation in China's trade expansion project called One Belt One Road (OBOR) has already been mentioned in the bibliography, the project was outlined as China-Mongolia-Russia Economic Corridor a trilateral co-operation in 2014 at Dusanbe Summit of the Shanghai Cooperation Organisation (SCO) (Engelberth I. - Sági, J. 2017). But even though there is a number of publications in this field, mentioning opportunities and obstacles as well, but there is still no exact evidence too foresee Mongolia's benefits from this project (Dondokov, Z. 2018; Graceffo, A. 2020) especially in case of SMEs. Erdei - Erdeiné Késmárki-Gally (2019) pointed out the technical obstacles in connecting Chinese and Mongolian (and Central Asian) railway systems as well. A review of the main body of literature regarding SMEs development and internationalization phenomenon in the developing countries has shown that there is a lack of empirical research on this subject.

Moreover, there is a scarcity of research with respect to SME's internationalization in developing countries, particularly encountering barriers, which were transited from a centrally planned to a market-led economic system at the beginning of 1990. Therefore, it is crucial to researchers, practitioners, and policymakers as scholarly advances on in a variety of different geographical areas that have been neglected to understand SMEs internationalization phenomenon. The main purpose of this research is to explore what barriers SMEs in transition countries facing during their internationalization process. By this paper, we contribute to the narrow existing literature in the field of the internationalization of SMEs in the transition countries by investigating SMEs in Mongolia in order to provide implications to researchers, practitioners, policymakers and SME owners or managers. First chapter presents the relevant literature review of the SME's internationalization and barriers they may encounter during their internationalization process in general. Secondly, the current SMEs development in Mongolia, key issues in the field of SMEs internationalization is examined. Then, the research methodology adopted in this research is described. Finally, the conclusions and suggestions are presented.

\section{Encountering issues and barriers of the internationalization in SMEs in Mongolia}

As of 2017, there were active 78,585 legal entities running business in Mongolia, 67,000 of which were SMEs. As defined in SME law of Mongolia, SMEs are registered business entities with less than 199 employees and 1.5 billion MNT annual turnover. Concerning economic beneficence, the mining sector is the main contributor to the Mongolian economy, which produces $24.5 \%$ of GDP individually, wholesale and retail sectors are the second biggest sector, which make up $15.7 \%$ of GDP. Following that, agriculture and manufacturing sectors generate $10.2 \%$ and $10.5 \%$ of GDP, respectively (Boojoo, L., 2019; Kozár, 2012). Zolzaya- Hong (2018) pointed out that SMEs account for $17.8 \%$ of the total GDP, $2.3 \%$ of the export, and provide 
$70 \%$ of the total employment in Mongolia. In accordance with World Bank report, Mongolia is rated in the place of 74 out of 190 countries in the matter of environments of doing business. Compared to the neighboring countries, it is ranked far below than China, Japan, Kazakhstan, and South Korea in this category. Moreover, being heavily reliant upon the mineral sector is one of the weaknesses for Mongolian economy, which is needed to be diversified by transforming its natural resource wealth into assets that support sustainable growth and prosperity (Doojav et al., 2020). Boojoo.L (2019) stated that there is a shortage of long-term financing means for SMEs in Mongolia, as well the interest rate of the short-term loan that is available on the financial market is sky high. These challenges indicate that the governmental institutions should provide more long-term loan with low minor interest rate in order to sustain SME development in the long run. Yet, in the transition countries, there are some critical problems because of high level bureaucracy, corruption, unstable political situation, the characteristic of transformed into new regime and low level of connection to relevant institutions. Evidence from the Mongolian case would be of high relevance for understanding potential barriers that might encounter in the internationalization of SMEs in the transition countries and lowering barriers to SME development for resource-rich developing countries as well.

\section{Research methodology}

The present study is based merely on the bibliographic search that covered all related studies executed in the field of internationalization of SMEs in transition countries. Two eligible touchstones were set from the perception in selecting articles and studies relevant to our study.

A. The research papers and studies covered topics of SMEs internationalization phenomenon that published or non-published in journals, books, and in conference proceedings.

B. Conceptual, empirical, methodological, or meta-analysis data, documents, and case studies.

The objective of this study is to outline a possible and effective methodology that will be applicable to Mongolia's case and give another different interpretation of determining methodology. Furthermore, by this paper, we also set a goal to provide methodological suggestions to investigate the key barriers of internationalization in SMEs in the transition countries. As mentioned previously, SMEs are the crucial contributor to the national economy, particularly in developing countries. As far, most countries transited from a centrally planned economy to a market economy at the beginning of 1990 fall in the category of transition economies and developing countries in terms of their economic development. In the research background section, we stated both the problems and barriers that occur during SMEs in transition countries in their internationalization process and methodology that was adopted more commonly in this field.

\section{Research paradigm}

Ganbold. M (2016) pointed out that a research paradigm is an ideology to be chosen at the first step of the study by the researcher directing the research at a greater distance. Two kinds of paradigms are used in the research: positivism, and interpretivism. In this study, the positivist paradigm used to understand the barriers to SMEs internationalization in Mongolia. Hence, the research using the positivist paradigm comprehends human behavior based on the experiments and analysis, while the research using the interpretivism paradigm formulate social reality based on the individual's opinion. 


\section{Research background}

This section provides a statement of all kinds of barriers that may occur during SMEs internationalization process based on previously conducted studies in various countries. A review of the literature reveals that the firm's country of origin, also named as context-specific factors, is one of the crucial factors to the SME's internationalization process. MarinovaMarinov (2017) studied the relevance of context-specific factors for firm internationalization in a transition context using the qualitative method. It is estimated that SMEs in transition countries deal with the common challenges that are usually encountered by SMEs in other economies as well. Also, they overcome challenges caused by institutional external and internal factors during their internationalization.

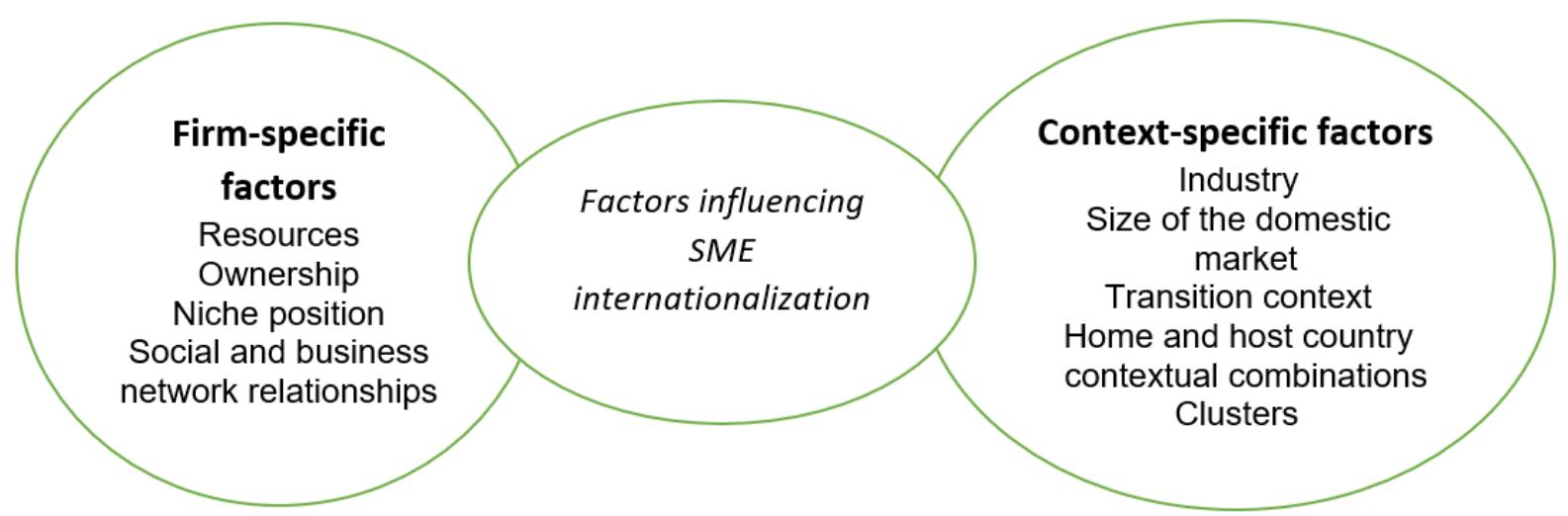

Figure 1. Factors influencing SME internationalization

Source: Marinova- Marinov, 2017

This is consistent with the result of other studies, Thai et al (2013) pointed out most of internationalization theories are not unsuited for explaining the internationalization of SMEs in transition countries because of distorted information channels, fragile market structures, imperfect property rights conditions, and unstable institutional environments. SMEs in the developed countries already have a good knowledge and experience of their domestic markets as well resources and capabilities that are essential to overcome potential barriers in a new foreign market (Thai et al., 2013). In the light of adopted methods all over the world, Hutchinson et al (2009) identified the initial barriers to the internationalization of small retailers based in the United Kingdom (UK) using qualitative design. Reaching the potential customers, understanding, and serving their needs require new approach to space and market, new methods and algorithms (Sikos T. et al. 2019). Following that, Gardó et al (2015) studied the barriers that are encountered to the retailing SME in Spain internationalization process using qualitative research method as well. In 2010, Al-Hyari et al identified some major barriers that constrain the export and export-related activities of SMEs in Jordan using a quantitative research method. While Rahman-Mendy (2019) adopted the mixed-method design to explore SMEs internationalization from an emerging market perspective. In 2016, Roy et al (2016) used quantitative research method to survey barriers to SMEs internationalization process from Indian context. Two more studies conducted in revealing barriers to SMEs internationalization used the quantitative methods alone, which raised doubts concerning understanding the barriers may be not well explored using single method.

\section{Conclusion}

In a broader context, the share of studies in the field of SMEs internationalization that chose quantitative or qualitative research methods individually is comparable high. While the portion 
of the research adopted both methods is less in terms of the numbers. Using one single method is not well suited to study the phenomenon like internationalization, so that we set and suggest a mixed-method research design to explore barriers to the SMEs' internationalization phenomenon in transition countries from various perspectives using diverse approaches as Mongolia as a case. Extending this line of inquiry, we also found that extant research has focused on the internationalization of SMEs in the developed countries and the obstacles facing the ongoing process of firm's internationalization, but the barriers to the internationalization of SMEs in the transition countries have received little attention in internationalization literature. The bibliographic evidence revealed in this study provided insight into the different types of actors engaging in SMEs internationalization process and the opportunity to comprehend external and internal barriers faced to the SMEs in the developing countries, especially transition economies. This study attempted to outline the main principles and framework of an effective methodology to examine the internationalization process of the SMEs in Mongolia (which can serve as a pattern for other transition and developing economies. However, we believe that there is still a need for further research in order to elaborate a well-functioning research and monitoring methodology as there is a number of obstacles and local factors that have to be quantified and incorporated into a tailor-made set of methodology.

\section{References}

1. Al-Hyari, K. - Al-Weshah, G. - Alnsour, M. (2012): Barriers to internationalisation in SMEs: evidence from Jordan. Marketing Intelligence \& Planning.

2. Bilguun, S. - Tsolmon, O. - Khuslen, B. - Bilguunzul, S. - Munkhbayar, G. Elbegjargal, E. (2018), Development and financing of small and medium enterprises

3. Boojoo, L. (2019): Leveraging SME Finance through Value Chains in the CAREC Landlocked Economies: Case of Mongolia.

4. Booltink, L.W. - Saka-Helmhout, A. (2018): The effects of R\&D intensity and internationalization on the performance of non-high-tech SMEs. International Small Business Journal, 36(1), pp.81-103.

5. Dondokov, Z. (2018): The economic corridor "China-Mongolia-Russia": problems and development prospects. IOP Conf. Ser.: Earth Environ. Sci. 190012052. doi :10.1088/1755-1315/190/1/012052; https://iopscience.iop.org/article/10.1088/1755-1315/190/1/012052/pdf

6. Doojav, G.O. - Luvsannyam, D. - Sukhbaatar, B. - Sodnomdarjaa, B. - Otgonbat, T. Batmunkh, K. - Gantumur, M. - Enkh-Amgalan, E. (2020): Development and Access to Finance of Small and Medium-Sized Enterprises in Mongolia. In: Zhang, Xi - Kwok Tai Chui - Ordez De Pablos (eds.): Innovative Management and Business Practices in Asia (pp. 265-294). IGI Global.

7. Engelberth I. - Sági J. (2017): Az Új selyemút kezdeményezés szerepe, céljai (The Role and the Goals of New Silkroad Initiative). Külügyi Szemle (Foreign Policy Review), Vol. 2017, No. 3, pp. 85-104. https://kki.hu/assets/upload/05_EngelberthSagi.pdf

8. Erdei A. - Erdeiné Késmárki-Gally Sz. (2019): Kína regionális kapcsolatainak fejlődése a 21. században (The development of China's regional relations). Annales book series, Vol. 12, Universitas Budapestiensis de "Metropolitan pp. 243-254. https://www.metropolitan.hu/upload/c511ab52b7d91e22ee27763f613a555b7a0e6336 .pdf

9. Ganbold, M. (2016): The impact of the small and medium enterprise support programmes on the livelihoods of micro-entrepreneurs using sustainable livelihood framework: a case study of Enterprise Mongolia Project Phase 2 by United Nations 
Development Programme in Mongolia: a thesis presented in partial fulfillment of the requirements for the degree of Master of Philosophy in Development Studies at Massey University, Palmerston North, New Zealand (Doctoral dissertation, Massey University).

10. Gardó, T.F. - García, H.C. - Descals, A.M. (2015): Internationalization of SME retailer: barriers and the role of public support organizations. International Journal of Retail \& Distribution Management.

11. Graceffo, A. (2020): Mongolia and the Belt and Road Initiative: The Prospects for the China-Mongolia-Russia Economic Corridor. ChinaBrief, Volume $20 \bullet$ Issue 12 • July 15, 2020, pp 35-39. https://jamestown.org/wp-content/uploads/2020/07/Read-the-0715-2020-CB-Issue-in-PDF.pdf?x73670

12. Gyene, P. (2020): China's Economic Progress and the Perceptions of the "New Silk Road" in Central Asia. In: Moldicz, C. (ed.) A Geopolitical Assessment of the Belt and Road Initiative. Budapest, Budapest Business School University of Applied Sciences (BGE), (2020) pp. 27-40.

13. Hovhannisyan, V. - Vasa, L. (2007): Armenian Rural Cooperatives and Marketing: Dairy Sector. Gazdálkodás (Scientific Journal on Agricultural Economics), 51(802016-569), pp.17-25.

14. Hutchinson, K. - Fleck, E. - Lloyd-Reason, L. (2009): An investigation into the initial barriers to internationalization: Evidence from small UK retailers. Journal of Small Business and Enterprise Development.

15. Kahiya, E.T. (2013): Export barriers and path to internationalization: A comparison of conventional enterprises and international new ventures. Journal of International Entrepreneurship, 11(1), pp.3-29.

16. Kozár, L. (2012): Rural Development, Based on Market Institutes. International Journal of Environmental, Cultural, Economic and Social Sustainability. 7 p 47.

17. Lkhagvasuren, T. - Xuexi, H. (2014): Analysis of the returns of small and mediumsized enterprises in Mongolia. Journal of Finance and Accounting, 2(3), pp.41-47.

18. Marinova, S. - Marinov, M. (2017): Inducing the internationalization of family manufacturing firms from a transition context. European Business Review.

19. Mendy, J. - Rahman, M. (2019): Supporting SMEs' internationalisation through a deeper understanding of human and technology barriers. Journal of Organizational Effectiveness: People and Performance.

20. Ngoma, M. - Ernest, A. - Nangoli, S. - Christopher, K. (2017): Internationalization of SMEs: does entrepreneurial orientation matter? World journal of entrepreneurship, management, and sustainable development.

21. Rahman, M. - Mendy, J. (2019): Evaluating people-related resilience and nonresilience barriers of SMEs' internationalization. International Journal of Organizational Analysis.

22. Roy, A. - Sekhar, C. - Vyas, V. (2016): Barriers to internationalization: A study of small and medium enterprises in India. Journal of International Entrepreneurship, 14(4), pp.513-538.

23. Singh, G. - Pathak, R.D. - Naz, R. (2010): Issues faced by SMEs in the internationalization process: results from Fiji and Samoa. International journal of emerging markets.

24. Sikos, T. - Kozák, T. - Kovács, A. (2019): New retail models in online and offline space. Deturope - The Central European Journal of Regional Development and $\begin{array}{lllllll}\text { Tourism } & \text { Vol. } & 11 & \text { Issue } & 3 & 2019, & \text { pp }\end{array}$ https://www.deturope.eu/img/upload/content_10435366.pdf 
25. Thai, M.T.T. - Chong, L.C. (2013): Dynamic experimental internationalization: Strategy of SMEs from a transition economy. Journal of International Entrepreneurship, 11(4), pp. 370-399.

26. Toulova, M. - Votoupalova, M. - Kubickova, L. (2015): Barriers of SMEs internationalization and strategy for success in foreign markets. International Journal of Management Cases, 17(1), pp.4-19.

27. Tuul, O. - Bing, S.J. (2019): Employee training in small and medium-sized enterprises in Mongolia. Proceedings of the Mongolian Academy of Sciences, pp.75-84.

28. Yener, M. - Doğruoğlu, B. - Ergun, S. (2014): Challenges of Internationalization for SMEs and Overcoming these Challenges: A case study from Turkey. Procedia-Social and Behavioral Sciences, 150, pp.2-11.

29. Zolzaya, E. - Hong, Z.X. (2018): The research of Mongolian SMEs human resource recruitment and selection in some problem. Proceedings of the Mongolian Academy of Sciences, pp.160-172. 